UDC $271.2-282.3(094.5)$

Dr Marija Draškić

profesor Pravnog fakulteta u Beogradu

\title{
O USTAVNOSTI I ZAKONITOSTI PROPISA O VERSKOJ NASTAVI*1
}

Ja bih svoj odgovor na vaš poziv za učešće na današnjoj javnoj raspravi podelila na dva dela.

Jedno je pitanje ocene zakonitosti Uredbe o organizovanju i ostvarivanju verske nastave i nastave alternativnog predmeta u osnovnoj i srednjoj školi (Uredba) i ono je jednostavnije. Naime, prilično je očigledno - po mom mišljenju - da je Uredba bila flagrantno nezakonita u trenutku kada je doneta, i to zbog sledećih razloga:

- prvo, prema čl. 20. Zakona o osnovnoj školi i čl. 24. st. 1. Zakona o srednjoj školi ministar prosvete imao je isključivu nadležnost da donosi nastavne planove i programe, dok je po čl. 5. st. 2. Uredbe bilo predviđeno da nastavni plan i program verske nastave sporazumno donose ministar prosvete i ministar vera, na usaglašen predlog tradicionalnih crkava i verskih zajednica;

- drugo, prema čl. 23. Zakona o osnovnoj školi i čl. 25. Zakona o srednjoj školi isključivu nadležnost da odobrava udžbenike imao je takođe ministar prosvete, dok je prema čl. 7. st. 1. Uredbe bilo predviđeno da udžbenike za versku nastavu odobrava ministar prosvete na usaglašen predlog tradicionalnih crkava i verskih zajednica;

* Rad primljen: 27. VI 2003.

1 Ovaj tekst predstavlja izlaganje prof. dr Marije Draškić na javnoj raspravi koju je 24. juna 2003. godine organizovao Ustavni sud Republike Srbije povodom predstavki i inicijativa za ocenu ustavnosti i zakonitosti Uredbe o organizovanju i ostvarivanju verske nastave i nastave alternativnog predmeta u osnovnoj i srednjoj školi (Službeni glasnik RS, br. 46/2001) i ustavnosti Zakona o izmenama i dopunama Zakona o osnovnoj školi (Službeni glasnik RS, br. 22/2002) i Zakona o izmenama i dopunama Zakona o srednjoj školi (Službeni glasnik RS, br. 23/2002). 
- treće, prema čl. 46. st. 5. Zakona o osnovnoj školi i čl. 48. st. 7. Zakona o srednjoj školi isključivu nadležnost da propisuje kriterijume i način ocenjivanja učenika imao je ministar prosvete, dok je čl. 11. st. 3 . Uredbe to pravo dato ministru prosvete ali tek pošto dobije zajednički predlog Ministarstva vera i tradicionalnih crkava i verskih zajednica;

- četvrto, prema čl. 67. st. 3. Zakona o osnovnoj školi i čl. 70. st. 7. Zakona o srednjoj školi isključivu nadležnost da utvrđuje vrstu stručne spreme nastavnika imao je - opet - ministar prosvete, dok je prema čl. 8. st. 2. Uredbe mogao da odlučuje samo na zajednički predlog Ministarstva vera i tradicionalnih crkava i verskih zajednica;

- peto, prema čl. 79. st. 1. Zakona o osnovnoj školi i čl. 73. st. 1. Zakona o srednjoj školi nastavnika je birao direktor škole na osnovu konkursa, a prema čl. 8. st. 3. Uredbe listu nastavnika verske nastave utvrđuje ministar prosvete na predlog tradicionalnih crkava i verskih zajednica;

- šesto, opisno ocenjivane za versku nastavu koje je ustanovio čl. 11. st. 1. Uredbe nije uopšte poznavao Zakon o srednjoj školi.

Drugo je pitanje komplikovanije i ono se odnosi na pitanje ustavnosti Zakona o izmenama i dopunama Zakona o osnovnoj školi i Zakona o izmenama i dopunama Zakona o srednjoj školi, budući da se pitanje ustavnosti Uredbe više ne postavlja, jer bi trebalo da je ona prestala da važi - a što je propušteno da se kaže u ova dva zakona.

Moje je mišljenje o ovom drugom pitanju da su i Zakon o izmenama Zakona o osnovnoj školi i Zakon o izmenama i dopunama Zakona o srednjoj školi neustavni, a osvrnuću se samo na tri najvažnija razloga koje ističem u prilog takvog stava.

Prvo. - Povelja o ljudskim i manjinskim pravima i građanskim slobodama Državne zajednice SiCG u čl. 27. st. 1. proklamuje da su verske zajednice ravnopravne i odvojene od države, dok Ustav Republike Srbije kao jedno od osnovnih ustavnih načela proklamuje načelo odvojenosti crkve od države (čl. 41. st. 2). To znači - kako ja razumem ustavni tekst - da kako država ne može da se meša u pitanja vere, tako isto ni crkva ne može imati jurisdikciju u nekim ekskluzivno sekularnim poslovima, kao što je sistem državnih škola. Da bismo proverili ovakav zaključak, ja vam nudim dva jednostavna testa.

Prvi test jeste pokušaj da odgovorite na hipotetično pitanje šta bi to trebalo da učini crkva pa da se smatra da je povređeno ovo ustavno načelo, ako nije povređeno ulaskom veronauke u sistem državnih škola. Da li bi, recimo, to bio zahtev crkve za uvođenje obaveznog crkvenog braka odnosno postojanje fakultativnosti forme braka (kao što je to slučaj trenutno u hrvatskom pravu) ili bi to možda bio zahtev da se usvajanje dece kao pravni institut poveri crkvi, o čemu je u javnosti - ruku na srce već bilo ponuda od strane jednog visokog činovnika Srpske pravoslavne crkve. Dakle, hoćemo li moći reći da ni ovakvi zahtevi crkve ne bi predstavljali povredu ustavnog principa o odvojenosti crkve i države? Ako je 
pak odgovor potvrdan, u čemu je razlika u odnosu na uvođenje veronauke u državne škole? Hoću reći, crkva je nevoljno i posle dugotrajnog protivljenja i osuđivanja prihvatila princip odvajanja crkve od države priznajući državi nezavisnost i autonomiju na njenom području, ali kod nas izgleda nije priznala državi pravo da odluči o tome šta u to područje spada.

Drugi test trebalo bi da odgovori na pitanje kakva je pozicija države vis-a-vis poslova verskih zajednica. Ima li država ikakve ingerencije u bilo kakvim pitanjima vere? Jer ako to što verske zajednice uređuju nastavne programe, udžbenike, način ocenjivanja i kvalifikacije i liste nastavnika nije mešanje u državne poslove, da vidimo ima li analogije u nečemu što čini država u domenu verskih poslova, a što crkva toleriše u okviru - takođe - poštovanja principa odvojenosti crkve i države. Znate i sami da takvih nadležnosti države u crkvenim stvarima apsolutno nema.

Štaviše, čak i blago upozorenje predsednika Državne zajednice SiCG, gospodina Svetozara Marovića, da bi i crkva trebalo da se reformiše u 21. veku, izazvalo je furioznu reakciju čak i samog Patrijarha Pavla o tome da se menjaju samo „ništavne stvari” a „radi površnog prilagođavanja duhu ovog veka”, te da oni koji se zalažu za promene „i sami postaju zarobljenici ništavila i prolaznosti”. Moje je konačno pitanje, dakle, da li su crkva i država ravnopravne u primeni principa odvojenosti crkve i države? i moj je odgovor da - kako stvari sada stoje - ravnopravnosti u odvojenosti države i crkve uopšte nema.

Drugo. - Odgovor na pitanje koje mesto i ulogu imaju religije u javnoj školi u uporednom i međunarodnom pravu glasi da jedinstvenog odgovora na ovo pitanje nema. On, naime, zavisi od toga kako je u pojedinim državama rešen odnos države i religije, ali je veliko šarenilo i u pravilima o tome da li veronauka - tamo gde se predaje - predstavlja učenje katihizisa, što znači podučavanje određenoj veri ili ima oblik predmeta koji podučava o religijama uopšte, istoriji, verskoj etici itd.

Poznato je da postoji više načina uređenja ovog odnosa i da se svi oni - sa uslovnostima svake podele - mogu podeliti na dve velike grupe.

U prvu grupu spadaju države u kojima postoji manja ili veća tesna povezanost između države i pojedine religije (model subordinacije i model koordinacije). Model subordinacije ima dve podvrste: kada je crkva podređena državi (recimo, tragovi cezaropapizma vide se u ulozi koju imaju engleska kruna i parlament po pitanju internih stvari anglikanske crkve, Grčka u kojoj je zakonom zagarantovana dominacija države nad crkvom) odnosno kada je država podređena određenoj religiji ili veroispovesti (Vatikan koji je pod suverenom vlašću rimskog pape, postrevolucionarni Iran itd.).

U drugu grupu spadaju države koje su od religije u većoj ili manjoj meri odvojene i njihov odnos može biti trojak:

a) konkordat (Austrija, Nemačka, Italija, Malta, Portugal, Španija i francuske pokrajine Alzas i Lorena) gde se pitanje nastave religije rešava na osnovu jednog ili više konkordata; 
- na primer, u Italiji fakultativna konfesionalna nastava religije, alternativa ovom predmetu jeste sloboda;

- u Nemačkoj je verska nastava obavezan školski predmet konfesionalno uređen, osim u pokrajini Bremen i gradu Berlinu, sa pravom učenika da izaberu nekonfesionalni alternativni predmet; itd.

b) državna crkva

- anglikanska tradicija u Velikoj Britaniji, ali se verska nastava izvodi kao nekonfesionalna i predaju je nastavnici;

- luteranska tradicija u Skandinaviji;

- u Norveškoj je do 1997. postojala luteranska verska nastava sa alternativom konfesionalne nastave neke druge religije ili nekonfesionalna nastava o religijama i etici, a od školske reforme 1997. postoji samo jedan nekonfesionalno-konfesionalni predmet,

- u Danskoj, nastavnici religije predaju akonfesionalan predmet,

- u Švedskoj, takođe, nekonfesionalni predmet, neutralan predmet o religijama i verskoj etici,

- u Holandiji, nauka o religijama uključena je u redovne predmete u osnovnoj školi, a u srednjim školama u nastavu mogu biti uključeni i sadržaji kao što je poznavanje Biblije i duhovnog života, a van školske nastave u prostorijama škole može sé organizovati i veronauka...

c) konfesionalna država (Grčka u kojoj je verska nastava izrazito konfesionalno zasnovana, bez mogućnosti izbora alternativnog predmeta) i

d) odvojenost države i crkve (Francuska, SAD, Slovenija) koja je u ovim državama potpuno dosledno sprovedena i koja zato ne poznaje mogućnost uvođenja veronauke ili konfesionalnu nastavu određene religije, makar taj model bio na snazi u većini evropskih država. Evo, ilustracije radi, stava Vrhovnog suda SAD u slučaju McColum v. Board of Education iz 1948, koji je doneo odluku da školska sredina Čempejn nije poštovala načelo razdvojenosti države i crkve jer je dozvolila veronauku (protestantsku, katoličku i jevrejsku) u javnim školama za vreme nastave. Sudija Blek napisao je da ,upotreba javnih zgrada za širenje religioznih doktrina, kao i školska administracija koja je učenicima omogućila veronauku, omogućili su da nestane odvojenost crkve od države". U potpunom skladu sa ovim načelom, po mišljenju suda, jeste nekonfesionalna nastava o religijama u javnoj školi. Štaviše, bez takve nastave, koja se zasniva na poznavanju istorije religija, po mišljenju suda, nepotpuno je obrazovanje koje pružaju javne škole.

Treće. - Za razliku od mog uvaženog kolege, profesora Sime Avramovića, sa kojim inače vodim polemiku na stranicama Anala Pravnog fakulteta u Beogradu o istom ovom pitanju, ja smatram da vrednosne sudove nikako ne smemo zaobići u ovoj diskusiji. Naime, smisao državne škole je u tome da postavlja temelje ne samo obrazovanja nego i vaspitanja budućih građana, pa je zbog toga pitanje vrednosti kojima se podučavaju mladi neodvojivo od drugih pitanja u ovoj raspravi. 
Ja smatram da je uvođenje veronauke u školske programe osnovnih i srednjih škola Srbije pogrešna odluka republičke Vlade i nije u skladu sa njenim javnim zalaganjem za modernu, efikasnu, a time i sekularnu državu. Ona znači da će se deca u školi vaspitavati delimično i u religioznom duhu, na crkvenim katihizisima koji imaju za cilj da mladima usade religijski pogled na svet. Taj pogled na svet projektuje netačnu sliku stvarnosti, jer se ne zasniva na naučnom znanju i iskustvu ljudske egzistencije, nego na dogmama, isključivostima i apsolutnoj poslušnosti pred autoritetima. Ja sam, za ovu priliku, odabrala samo nekoliko citata koji dobro prezentiraju stavove Srpske pravoslavne crkve o nekim važnim pitanjima savremenog života.

Prvo, evo kako crkva podučava vernike o abortusu:

„Nasuprot feminističkim političkim sloganima, estetika, duhovna i fizička stvarnost vršenja pobačaja se smanjuje. Ona se približava obliku smrtonosnog medicinskog uništenja. To 'oslobađa' žene i njihove bebe na isti način kao što je Aušvic 'oslobađao' Jevreje. Ono čini istu stvar ženama kao i pornografija - koristi, ocrnjuje i svodi žene na nivo seksualnih robova, s jedne strane, i proste 'produktivne građane', koji štite svoju karijeru, s druge strane. To pretvara živodajnu utrobu u mrtvačku komoru u kojoj namučeno, uniženo i napaćeno dete umire tiho, uz nečujne krike." (Videti Abortus je ubistvo - stav Crkve pravoslavne o utrobnom čedomorstvu, EUO Eparhije žičke, 2000, str. 14-15)

Ekstremna netrpeljivost prema svemu što dolazi iz zapadnog kulturno-civilizacijskog kruga vidi se iz ovih reči:

"Satanske sile - zavereničke, političke, kulturne, liberalne, levičarske vode Novi svetski poredak koji je nesumnjivo... nadahnut Satanom." Glavni izvor svih zala je Amerika ,u kojoj postoji raspad morala i ... mentalnog zdravlja”. Zapad je u celini podvrgnut delovanju ,adskih sila... zaveri protiv hrišćanstva, bezbožnoj kulturi”. „Među Srbima - zaključuje Pravoslavlje - neće biti poremećenih ljudi koji bi hteli da nas zaraze smrtonosnom bolešću zapadne kulture. Daleko im lepa kuća sa ovom njihovom naprednošću".

Reč crkve o Novom Beogradu:

„Novi Beograd najveći je satanski eksperiment, vrhunac komunističkog egzibicionizma... sam po sebi nesreća, duhovni gulag, duhovni 'Goli otok'. Grad novog... novi blokovi, nova svetilišta, nove škole, nova obdaništa, nove prodavnice, nov Studentski grad, nova Hala sportova, nov auto-put - za novu decu, za nove studente, za nove ljude. Grad u pustinji, grad bez crkvi, grad bez istorije, grad obezboženih, grad nekrštenih, grad rasrbljenih, grad mrtvih duša, grad budućih 'arijevaca'... grad gde je do vrhunca dovedeno zlo". (Videti Pravoslavlje, 1. februar 2001)

Najzad, evo kako SPC govori o vaspitavanju pravoslavne devojčice:

„Pravoslavna devojčica uči od najranijeg detinjstva da postane domaćica zajedno sa majkom, opslužuje vredno ukućane kroz svakodnevne 'ženske' obaveze, odrastajući potpuno svesna da su potrebe njene braće na prvom mestu. Majka joj poverljivo saopštava da su bolovi rađanja te- 
ret ženske grešnosti sa kojom se treba pomiriti... Uči je da su žene u pojedinim periodima nečiste, da je to u crkvenom pogledu vrlo važno, te da je menstrualni ciklus ženska slabost i ljudski nedostatak o kome moraju pred svima da ćute, da samim govorom ne bi počinile greh.... Majka takođe upoznaje ćerku sa tajnama grešnih pomisli prilikom zaljubljivanja koje se moraju ispovediti i upućuje je na to da je svaki seksualni odnos, uključujući tu čak i bračni, veliki greh ukoliko mu nije cilj rađanje dece. Seksualno vaspitavanje je izum đavola te sledstveno tome žene treba da rađaju po volji Boga što više, jer žena na taj način izražava svoj patriotizam" (knjiga Sta treba da zna svaka pravoslavna devojčica, Mitropolija crnogorsko-primorska, 2000).

Takođe, nije prihvatljiva ni tendencija poistovećivanja religije i duhovnosti, vere i sistema moralnih vrednosti. Nije istina da su jedino religije baštinici najvažnijih moralnih vrednosti čovečanstva, već su te vrednosti postale sastavni deo javnog poretka svih prosvećenih i civilizovanih društava. Ljubav prema bližnjem nije nalog vere, nego iskonska potreba svakog ljudskog bića da se dokaže i da opstane. Važnost porodice ne počiva na autoritetu crkve, već na zadovoljenju osnovne potrebe u životu svake individue, a to je potreba za ljudskim kontaktom. Pojam greha telesne ljubavi protivreči sistemu vrednosti modernog vremena, u kome dominiraju pravo na slobodu i pravo na samoodređenje. Drugim rečima, obrazovanje u državnim školama u Srbiji 21. veka treba da počiva na sumnji, a ne na veri; na naučnom saznanju, a ne na kreacionizmu; na životu, slobodi i autonomiji, a ne na nametnutom grehu.

Zbog toga je, umesto veronauke, u državne škole trebalo uvesti predmet koji bi na vrednosno neutralan, racionalan i kritički način upoznavao učenike sa opštom istorijom svih religija i verskom etikom. Takav predmet oblikovalo bi Ministarstvo prosvete, formirajući nastavni plan i program, odabirajući udžbenike i birajući za veroučitelje diplomirane pedagoge, a ne zvanične predstavnike verskih zajednica. Nastavu tog predmeta pohađali bi svi učenici, bez razlike u pogledu toga koje su vere i da li uopšte imaju sopstvena verska ubeđenja. Takva, dobro organizovana i pripremljena moderna nastava o religijama, o njihovim univerzalnim i neprolaznim vrednostima, o njihovom uticaju na istoriju i umetnost, na razvoj ličnosti i društva bila bi dobrodošla. Objektivna i pluralistički intonirana znanja o religijama i duhovnosti neophodna su za razumevanje filozofije, istorije, književnosti, slikarstva, arhitekture i mnogih drugih oblasti ljudskog stvaralaštva i svetske tradicije, a sastavni su deo opšte kulture i civilizacije. 